\title{
$1064 \mathrm{~nm}$ rotational Raman lidar for particle extinction and lidar-ratio profiling: cirrus case study
}

\author{
Moritz Haarig $^{1}$, Ronny Engelmann ${ }^{1}$, Albert Ansmann ${ }^{1}$, Igor Veselovskii ${ }^{2}$, David N. Whiteman ${ }^{3}$, and \\ Dietrich Althausen ${ }^{1}$ \\ ${ }^{1}$ Leibniz Institute for Tropospheric Research, Leipzig, Germany \\ ${ }^{2}$ Physics Instrumentation Center, Moscow, Russia \\ ${ }^{3}$ NASA, GSFC, Greenbelt, Maryland, USA \\ Correspondence to: Moritz Haarig (haarig@tropos.de)
}

Received: 25 March 2016 - Published in Atmos. Meas. Tech. Discuss.: 12 April 2016

Revised: 8 August 2016 - Accepted: 11 August 2016 - Published: 1 September 2016

\begin{abstract}
For the first time, vertical profiles of the $1064 \mathrm{~nm}$ particle extinction coefficient obtained from Raman lidar observations at $1058 \mathrm{~nm}$ (nitrogen and oxygen rotational $\mathrm{Ra}$ man backscatter) are presented. We applied the new technique in the framework of test measurements and performed several cirrus observations of particle backscatter and extinction coefficients, and corresponding extinctionto-backscatter ratios at the wavelengths of 355, 532, and $1064 \mathrm{~nm}$. The cirrus backscatter coefficients were found to be equal for all three wavelengths keeping the retrieval uncertainties in mind. The multiple-scattering-corrected cirrus extinction coefficients at $355 \mathrm{~nm}$ were on average about 20-30\% lower than the ones for 532 and $1064 \mathrm{~nm}$. The cirrus-mean extinction-to-backscatter ratio (lidar ratio) was $31 \pm 5 \mathrm{sr}(355 \mathrm{~nm}), 36 \pm 5 \mathrm{sr}(532 \mathrm{~nm})$, and $38 \pm 5 \mathrm{sr}$ $(1064 \mathrm{~nm})$ in this single study. We further discussed the requirements needed to obtain aerosol extinction profiles in the lower troposphere at $1064 \mathrm{~nm}$ with good accuracy $(20 \%$ relative uncertainty) and appropriate temporal and vertical resolution.
\end{abstract}

\section{Introduction}

Routine, height-resolved observations of the particle extinction coefficient in the atmosphere are only possible with lidar (Ansmann and Müller, 2005). The particle extinction coefficient is one of the key parameters in the description of the impact of clouds and aerosols on environmental, weather, and climate processes, and in the retrieval of microphysical prop- erties of the detected cloud and aerosol layers. Two different lidar techniques are available for the measurement of aerosol and cloud extinction profiles, the Raman lidar method (Ansmann et al., 1990, 1992a; Ansmann and Müller, 2005) and the High Spectral Resolution Lidar (HSRL) technique (Shipley et al., 1983; Grund and Eloranta, 1990; Hair et al., 2001; Eloranta, 2005). An HSRL is measuring strong Rayleigh backscatter signals so that likewise short signal averaging periods are sufficient to retrieve high-quality extinction profiles. The technique is thus well suited for airborne and spaceborne applications (Wandinger et al., 2002; Hair et al., 2008; Esselborn et al., 2008; Burton et al., 2012; Illingworth et al., 2015). The Raman lidar method is based on comparably weak nitrogen and oxygen Raman backscatter-lidar returns so that longer signal averaging times are required for an accurate extinction profiling. However, the lidar setup is relatively simple and robust and therefore the Raman lidar technique has proven to be advantageous for long-term ground-based measurements (Turner et al., 2001; Pappalardo et al., 2014; Baars et al., 2016). This article deals with first atmospheric measurements with a novel rotational Raman channel at $1058 \mathrm{~nm}$ implemented in an operational Raman lidar to allow extinction profiling simultaneously at 355, 532, and $1064 \mathrm{~nm}$.

The Raman lidar technique is used to measure particle backscatter and extinction coefficients, and the extinctionto-backscatter ratio (lidar ratio) since more the 25 years (Ansmann et al., 1990, 1992a, 1993; Ferrare et al., 1993, 1998). Single-wavelength Raman lidars transmit laser pulses at 308 or $355 \mathrm{~nm}$, and record height profiles of signals elastically backscattered by air molecules and particles (at 308 
or $355 \mathrm{~nm}$ ) and inelastically (Raman) backscattered by nitrogen molecules at 332 or $387 \mathrm{~nm}$ (vibrational-rotational spectrum), respectively. In the next step, dual-wavelength Raman lidar came into operation (Müller et al., 1998; Ansmann et al., 2000; Mattis et al., 2002; Wandinger et al., 2002; Murayama et al., 2004) with laser wavelengths at 355 and $532 \mathrm{~nm}$ and respective vibrational-rotational nitrogen Raman channels at 387 and $607 \mathrm{~nm}$. The aerosol Raman lidar technique opened a solid way for comprehensive studies of anthropogenic pollution, desert dust, volcanic dust, and biomass burning smoke at several wavelengths (e.g., Mattis et al., 2004; Müller et al., 2005; Tesche et al., 2009a; AladosArboledas et al., 2011; Groß et al., 2011, 2012; Nicolae et al., 2013; Kanitz et al., 2014; Veselovskii et al., 2016) and found broad application in the European Aerosol Research Lidar Network, EARLINET (e.g., Amiridis et al., 2005; Papayannis et al., 2008; Mona et al., 2014; Pappalardo et al., 2014). Particle extinction profiling is also a basic requirement for a successful retrieval of microphysical aerosol properties by means of inversion methods (Müller et al., 1998; Müller et al., 2000; Müller et al., 2013; Ansmann and Müller, 2005; Veselovskii et al., 2002, 2016).

However, it remained an open issue throughout the years to measure the aerosol extinction coefficient at $1064 \mathrm{~nm}$. Stateof-the-art multiwavelength aerosol lidars use Nd:YAG lasers transmitting laser pulses at 355, 532 and $1064 \mathrm{~nm}$. Techniques have been developed to determine height profiles of particle backscatter and extinction coefficients at 355 and $532 \mathrm{~nm}$, but not at $1064 \mathrm{~nm}$. Only the $1064 \mathrm{~nm}$ backscatter coefficient is delivered. The improved coverage of the wavelength spectrum by backscatter and extinction pairs at all three Nd:YAG wavelengths would permit an improved, more robust characterization of aerosols in terms of optical and microphysical properties with lidar.

Recently, Veselovskii et al. (2015) presented highquality aerosol measurements with an interference-filterbased $532 \mathrm{~nm}$ rotational Raman lidar. This successful feasibility study paved the way to design a $1058 \mathrm{~nm}$ interference filter concept for successful particle extinction profiling at $1064 \mathrm{~nm}$. In this article, we report the first lidar observations of particle extinction at $1064 \mathrm{~nm}$ by using such $1058 \mathrm{~nm}$ interference filters. The implementation of a $1058 \mathrm{~nm}$ rotational Raman channel into an operational 355/532 nm Raman lidar is presented. A first three-wavelength Raman lidar measurement performed in a thick cirrus layer is shown and discussed. In addition, the potential of the new method to allow for aerosol extinction profiling in the lower troposphere with appropriate temporal and vertical resolution and accuracy is discussed.

\section{Instrumentation}

The methodological background of particle backscattering and extinction profiling with rotational and vibrationrotational Raman lidars was recently reviewed by
Veselovskii et al. (2015) and is partly based on the studies of Whiteman (2003a, b). The theoretical framework, presented with focus on the Raman lidar applications at 355 and $532 \mathrm{~nm}$ wavelength, can be used for the retrieval of particle backscattering and extinction at $1064 \mathrm{~nm}$ wavelength as well.

We implemented the new $1058 \mathrm{~nm}$ rotational Raman channel in our containerized multi-wavelength polarization/Raman lidar BERTHA (Backscatter Extinction lidar-Ratio Temperature Humidity profiling Apparatus) (Althausen et al., 2000; Haarig et al., 2015). BERTHA has been used over the past 20 years in 12 major field campaigns in Europe, Asia, Africa and the Caribbean (Wandinger et al., 2002; Ansmann et al., 2002; Franke et al., 2003; Tesche et al., 2009b; Tesche et al., 2011; Haarig et al., 2015). In 2012, BERTHA was re-designed to allow particle linear depolarization measurements at 355, 532, and $1064 \mathrm{~nm}$, simultaneously. During our last field campaign, the Saharan Aerosol Long-Range Transport and Aerosol-Cloud-Interaction Experiment SALTRACE (Barbados, 4-week campaigns in the summers of 2013 and 2014, and a 3-week campaign in the winter of 2014), BERTHA enabled us to derive vertical profiles of particle linear depolarization ratio and backscatter coefficients at three wavelengths and, by means of measured vibration-rotational Raman signals, of particle extinction and extinction-to-backscatter ratio (lidar ratio) at two wavelengths ( 355 and $532 \mathrm{~nm}$ ). BERTHA permits us in addition to measure $532 \mathrm{~nm}$ particle extinction profiles by means of the HSRL technique at $532 \mathrm{~nm}$ (Althausen et al., 2012). The complex lidar setup will be described in detail in the SALTRACE special issue of ACP (Haarig et al., 2016).

Two Nd:YAG lasers (Continuum, Powerlite) transmit linearly polarized laser pulses at 355 and $1064 \mathrm{~nm}$ (first laser) and at $532 \mathrm{~nm}$ (second laser). Two additional linear polarizers clean the polarization of the outgoing light. The repetition rate is $30 \mathrm{~Hz}$ and the pulse length $8-10 \mathrm{~ns}$. The pulse energies can be as high as $1000 \mathrm{~mJ}(1064 \mathrm{~nm}), 800 \mathrm{~mJ}(532 \mathrm{~nm})$ and $120 \mathrm{~mJ}(355 \mathrm{~nm})$ in the ideal case of well-working optical elements in the transmission unit of the lidar. However, the pulse energies were only about $50 \%$ of these maximum values during the October 2015 measurements. The beams are expanded 10-fold and pointed into the atmosphere at an off-zenith angle of $5^{\circ}$ to avoid the influence of specular reflection by ice crystals in cirrus layers on the backscattered signals. The receiver field of view (RFOV) is $0.8 \mathrm{mrad}$. A $53 \mathrm{~cm}$ Cassegrain telescope collects the backscattered light. The signals are detected with a range resolution of $7.5 \mathrm{~m}$ and a time resolution of $10 \mathrm{~s}$. To avoid overloading of the photomultipliers (PMTs, photon counting mode) in the near range we restricted the maximum count rate to $20 \mathrm{MHz}$ for the signal maximum at about $500 \mathrm{~m}$ height. This was achieved by using neutral density filters in front of the photomultipliers. The reduction of the backscatter signal strength is small for the Raman channels. No neutral density filter was used in the $1058 \mathrm{~nm}$ Raman channel in the measurement presented 
in the next section. Systematic effects on the extinction retrieval caused by the receiver optics (resulting, e.g., from polarization-dependent transmission and reflection efficiencies) can be excluded.

A sketch of the receiver unit is given in Fig. 1. We replaced the $1064 \mathrm{~nm}$ interference filter in the total $1064 \mathrm{~nm}$ backscatter signal channel by the $1058 \mathrm{~nm}$ interference filter (now used as the $1058 \mathrm{~nm}$ rotational Raman channel), and we removed the linear sheet polarizer of the $1064 \mathrm{~nm}$ cross-polarized signal channel and used this channel as the total $1064 \mathrm{~nm}$ backscatter signal channel. As mentioned, the design and realization of the $1058 \mathrm{~nm}$ interference filter used for $1064 \mathrm{~nm}$ backscatter and extinction profiling was motivated by the successful demonstration of highquality aerosol measurements with an interference-filterbased $532 \mathrm{~nm}$ rotational Raman lidar (Veselovskii et al., 2015). The same methodological approach, for the laser wavelength of $532.07 \mathrm{~nm}$, is applied here for the wavelength of $1064.14 \mathrm{~nm}$. The interference filter is centered at about 1058 nm (Alluxa, Santa Rosa, CA, http://www.alluxa.com). The transmission band is from 1053 to $1062 \mathrm{~nm}$ with a transmission $>90 \%$ in this wavelength range. For the laser wavelength of $1064.14 \mathrm{~nm}$, the transmission is specified to be $0.005 \%$. Broad-band blocking by more than 4 orders of magnitude from 350 to $1100 \mathrm{~nm}$ is realized. All filter-related transmission and blocking specifications are taken from the manufacturer's data sheets, provided by Alluxa.

When using a laser wavelength of $1064.14 \mathrm{~nm}, 88 \%$ of the total intensity of the rotational Raman backscatter spectrum (anti-Stokes lines) can pass the 1053-1062 nm filter. The filter width of $9 \mathrm{~nm}$ restricts the detection of $1058 \mathrm{~nm}$ Raman signals to nighttime sky background conditions. The detected Raman backscatter intensity is only weakly temperaturedependent (4\% increase of the measured rotational Raman signal for a temperature decrease from 300 to $230 \mathrm{~K}$ ). To guarantee no cross-talk contributions in the rotational Raman channel even in the case of extremely high elastic backscattering in ice clouds, we used two of the $1058 \mathrm{~nm}$ Raman filters in front of the PMT.

With these two filters, we achieved an overall blocking of elastic backscatter light in the $1058 \mathrm{~nm}$ Raman channel by better than $10^{-8}$. According to Ansmann et al. (1992b), the Raman filters must be able to suppress elastic backscatter signals resulting from specular reflection by ice crystals by up to 5-6 orders of magnitude, when pointing to the zenith. Operation of the lidar at an off-zenith angle of $5^{\circ}$ reduces the necessary suppression to about $10^{-4}$ because specular reflection is not detectable with this tilted lidar.

The data analysis is performed following the EARLINET data analysis protocol (Pappalardo et al., 2004). In the computation of Rayleigh backscattering and extinction contributions to the measured lidar signals, we used GDAS (Global Data Assimilation System) height profiles of temperature and pressure of the National Weather Service's National Centers for Environmental Prediction (NCEP, NOAA's

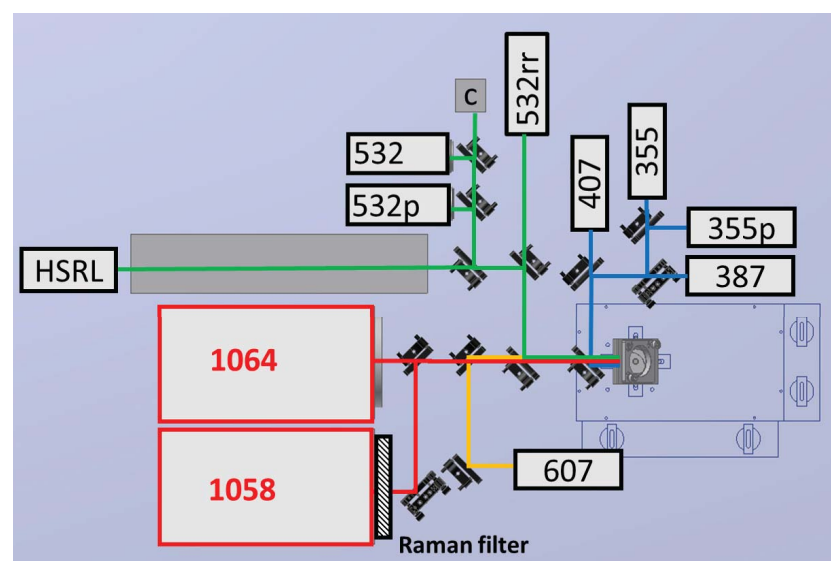

Figure 1. Sketch of the receiver unit of the lidar BERTHA with 13 detection channels (all operated in the photon counting mode): three elastic backscatter channels $(355,532$ and $1064 \mathrm{~nm})$, two crosspolarized elastic backscatter channels (355p, 532p, index p for perpendicular), two nitrogen vibrational-rotational Raman channels (387 and $607 \mathrm{~nm}$ ), three rotational Raman channels (532rr, grating monochromator technique) (Arshinov et al., 2005), one rotational Raman channel (1058 nm), a water-vapor vibrational-rotational Raman channel at $407 \mathrm{~nm}$ and a HSRL channel at $532 \mathrm{~nm}$. All detectors are photomultiplier tubes (PMTs) from Hamamatsu (H10721P110 , except for 1058 and $1064 \mathrm{~nm}$ ). For the 1058 and $1064 \mathrm{~nm}$ channels the PMTs R3236 from Hamamatsu are used. To reduce the signal-to-noise ratio, they are cooled down to lower than $-30^{\circ} \mathrm{C}$.

Air Resources Laboratory ARL, https://www.ready.noaa. gov/gdas1.php).

\section{Results}

First test measurements with the new Raman channel were performed on 5 October 2015. Figure 2 presents an observation performed on 12 October 2015 with a well-aligned lidar during a long-lasting cirrus event. Cirrus provides almost optimum conditions for checking the performance of the new lidar approach. The overlap between the laser beam and the receiver field of view (RFOV) is complete in the far range of the lidar and does not introduce any bias in the retrieval products. Furthermore, the suppression of elastic backscatter light in the used $1058 \mathrm{~nm}$ Raman channel can be checked at extremely large ice-crystal backscatter conditions. In cirrus, the particle backscatter, extinction, and lidar-ratio profiles for all three wavelengths $(355,532$, and $1064 \mathrm{~nm})$ should be rather similar because of the expected almost wavelengthindependent backscattering and extinction properties when the laser wavelengths are small compared to the size of ice crystals. In Fig. 3, we averaged 216000 laser shots (transmitted within $2 \mathrm{~h}$ ). To reduce the uncertainty in the retrieval products caused by signal noise to a tolerable level of $20 \%$, we smoothed the temporally averaged signal profiles in the retrieval of the cirrus particle backscatter coefficient with a vertical window length of $200 \mathrm{~m}$. The extinction profiles in 

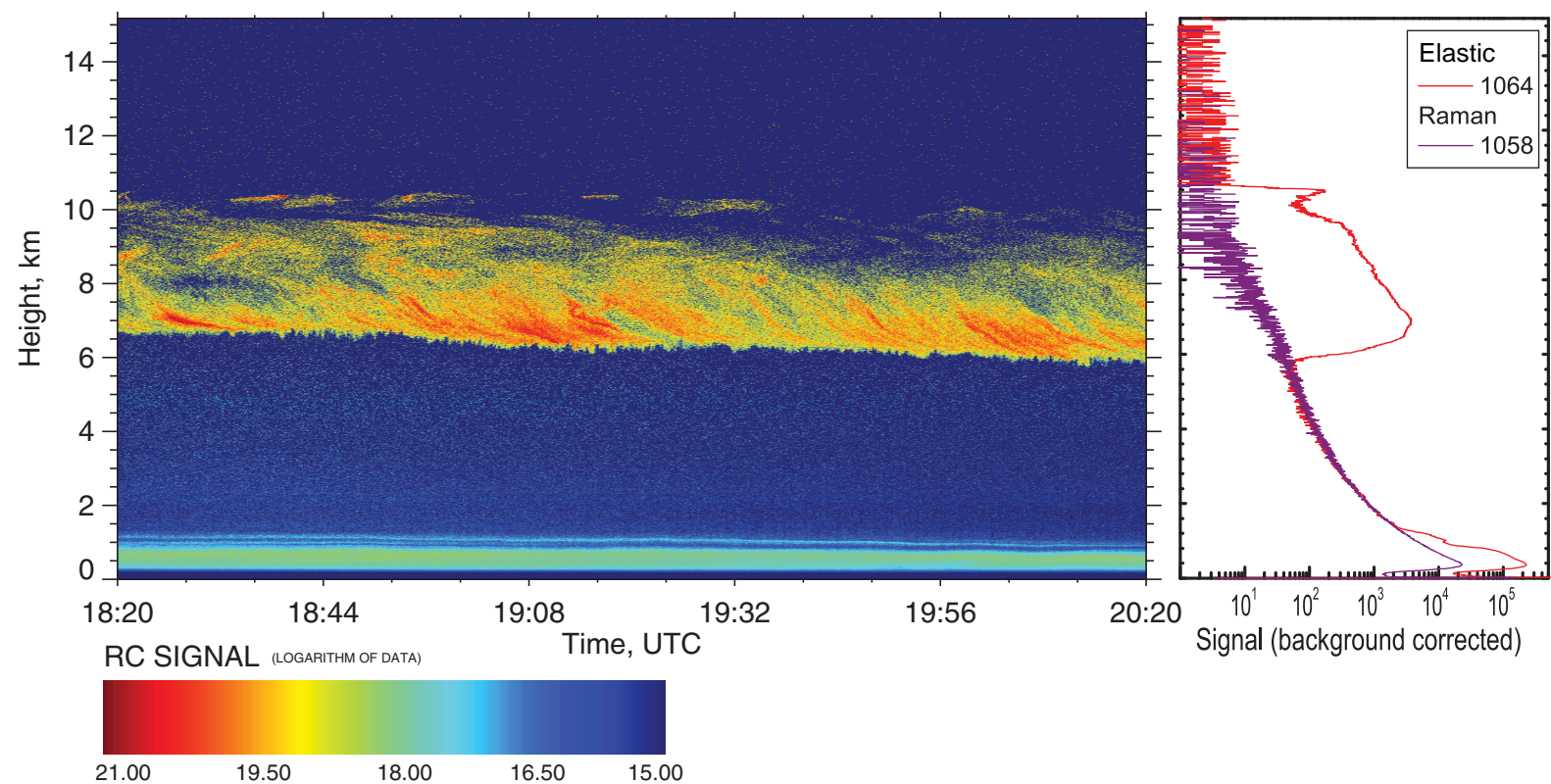

Figure 2. Cirrus observation at Leipzig, Germany, on 12 October 2015, 18:20-20:20 UTC. The range-corrected 1064 nm lidar return signals ( $7.5 \mathrm{~m}$ resolution) indicate an ice cloud layer between 6.5 and $10.5 \mathrm{~km}$ height with virga in the lower part. In the right panel, the signal profiles (rotational Raman channel centered at around 1058 and $1064 \mathrm{~nm}$ elastic-backscatter channel) are averaged over the $2 \mathrm{~h}$ period shown in the left panel.
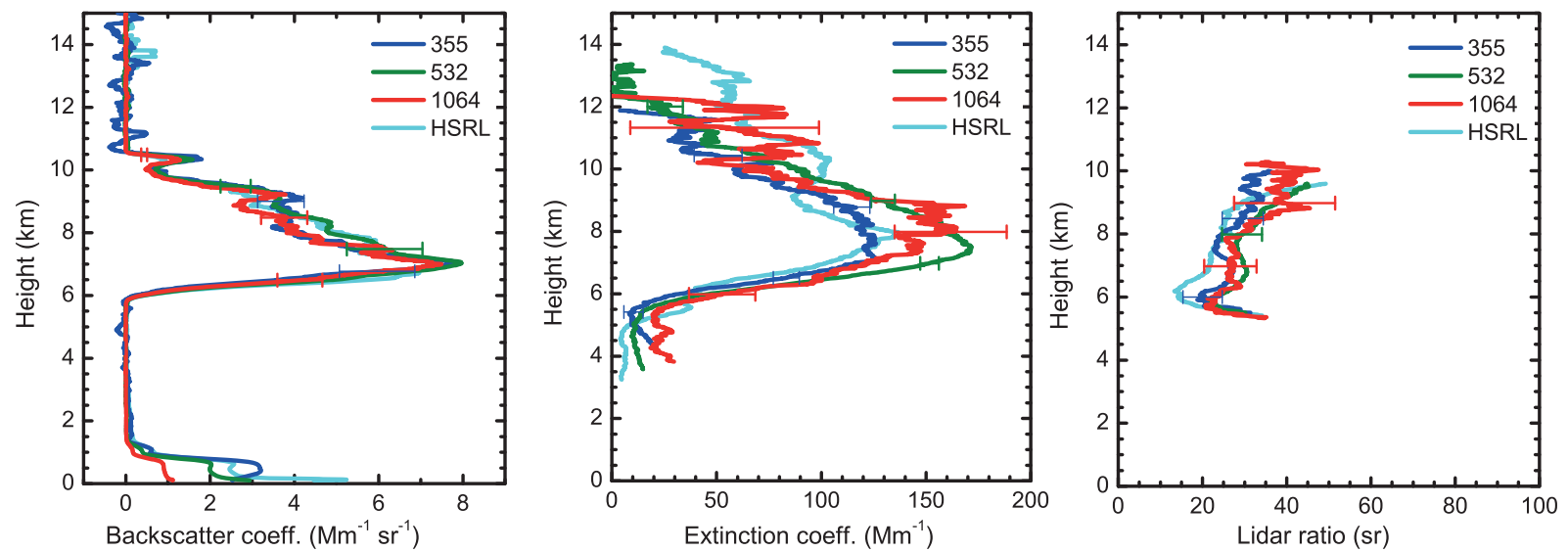

Figure 3. Triple-wavelength Raman lidar observation of cirrus particle backscatter coefficients (left), extinction coefficients (center), and corresponding lidar ratios (right). The $2 \mathrm{~h}$ lidar measurement shown in Fig. 2 was taken at Leipzig on 12 October 2015, 18:20-20:20 UTC. In addition to the Raman lidar profiles, HSRL profiles $(532 \mathrm{~nm})$ are shown. Error bars show the uncertainty caused by signal noise in the case of the Raman lidar profiles. Uncertainties caused by atmospheric input parameters (temperature and pressure profiles) are small (in the case of extinction typically $5 \mathrm{Mm}^{-1}$, in the worst case up to $10 \mathrm{Mm}^{-1}$ ) (Ansmann et al., 1992a).

Fig. 3 were obtained from a least-squares linear regression analysis applied to the 387,607 , and $1058 \mathrm{~nm}$ Raman signal profiles. The window lengths are $2000 \mathrm{~m}$ in the case of 355 and $532 \mathrm{~nm}$, and $2500 \mathrm{~m}$ and $3200 \mathrm{~m}$ below and above $9 \mathrm{~km}$ height, respectively, in the case of $1064 \mathrm{~nm}$ and the $532 \mathrm{~nm}$ HSRL extinction profile. The lidar ratios are calculated for the same coarse height resolution as the extinction values. Multiple-scattering effects are not corrected in Fig. 3. The impact will be discussed below. The calibration of the backscatter coefficient profiles was performed within the height range just above the cirrus layer $(12-15 \mathrm{~km}$ height, 355 and $532 \mathrm{~nm}$ ) or below the ice cloud (between 4 and $5.5 \mathrm{~km}$ height, $1064 \mathrm{~nm}$ ). The particle backscatter coefficient was set to $10^{-2} \mathrm{Mm}^{-1} \mathrm{sr}^{-1}$ at all three wavelengths. This means that Rayleigh scattering determines the total calibration backscatter coefficient in the calibration height range for 355 and $532 \mathrm{~nm}$. 
As can be seen in Fig. 2, the ice cloud layer showed a stable base height at $6.5 \mathrm{~km}$. The top height was detected at $10.5 \mathrm{~km}$, probably coinciding with the tropopause. The backscatter intensity increased by 2 orders of magnitude at cloud base according to the $1064 \mathrm{~nm}$ elastic backscatter signal (right panel in Fig. 2). As mentioned, to avoid strong specular reflection effects the laser beams were pointing to an off-zenith angle of $5^{\circ}$. The Raman signal profiles do not show any interference by strong elastic backscatter by ice crystals.

The $4 \mathrm{~km}$ deep, comparably homogeneous cirrus layer provided favorable conditions for a proper determination of the cirrus optical properties. The $2 \mathrm{~h}$ mean height profiles of particle backscatter and extinction coefficients, and lidar ratio at 355, 532, and $1064 \mathrm{~nm}$ are shown in Fig. 3. To present the full potential of the BERTHA lidar for aerosol and cloud research, HSRL solutions (for $532 \mathrm{~nm}$ ) are shown as well.

Keeping the uncertainty bars into consideration, similar profiles of the particle backscatter coefficients are obtained at all three wavelengths with all applied methods (Raman lidar and HSRL methods). All profiles are based on the analysis of the profiles of the ratio of the elastic backscatter signal to the molecule signal.

In the case of the extinction profiles, a good agreement between the 532 and $1064 \mathrm{~nm}$ extinction profiles (Raman lidar solutions) is visible. The $1064 \mathrm{~nm}$ extinction profile is however comparably more noisy. The $355 \mathrm{~nm}$ extinction coefficients are considerably smaller (by $20-40 \mathrm{Mm}^{-1}$, about 20 $25 \%$ ) than the $532 \mathrm{~nm}$ extinction values. In the case of the $532 \mathrm{~nm}$ HSRL solutions not all necessary corrections were applied (e.g., proper consideration of all cross-talk effects and near-range iodine-absorption saturation effects). This explains the deviations from the other profiles. We will use this case in a follow-up paper which will focus explicitly on the performance of the HSRL branch of BERTHA.

Multiple-scattering (MS) effects are not corrected in Fig. 3. According to Seifert et al. (2007), the MS factor, defined as the apparent (observed) extinction coefficient divided by the respective single-scattering (SS) extinction coefficient, is 0.6 at cirrus base and larger than 0.9 at cloud top for BERTHA with an RFOV of $0.8 \mathrm{mrad}$. The computations were performed for $532 \mathrm{~nm}$. MS effects are caused by strong forward-scattered laser radiation which remains in the RFOV so that the effective attenuation of laser radiation by ice crystal scattering is significantly reduced and leads to an apparent (effective) extinction coefficient and lidar ratio, about a factor of 1.1-1.8 lower than the respective SS values. For Fig. 3, we can conclude that the MS-corrected extinction values are close to $200 \mathrm{Mm}^{-1}(355 \mathrm{~nm})$ and $250 \mathrm{Mm}^{-1}(532 \mathrm{~nm})$ around $7-8 \mathrm{~km}$ height (cirrus base), and $85 \mathrm{Mm}^{-1}(355 \mathrm{~nm})$ and $110 \mathrm{Mm}^{-1}(532,1064 \mathrm{~nm})$ around 9-10 km height (cirrus top). Here we assume that MS effects are wavelengthindependent. The cirrus SS-related optical depth is close to 0.46 at $355 \mathrm{~nm}, 0.59$ at $532 \mathrm{~nm}$, and around 0.6 at $1064 \mathrm{~nm}$ when considering the extinction values from the Raman lidar observations between 6 and $10 \mathrm{~km}$ height.

Reasons for the deviation of the $355 \mathrm{~nm}$ extinction profile could be an increase in the MS effect with decreasing wavelength. Another reason could be related to the cirrus crystal size distribution which caused stronger extinction at 532 and $1064 \mathrm{~nm}$ than at the shorter wavelength of $355 \mathrm{~nm}$. However, accompanying Doppler lidar observations of crystal terminal velocity (about $0.7 \mathrm{~m} \mathrm{~s}^{-1}$ at cloud base) indicate large crystals (with diameters typically exceeding 300-400 $\mu \mathrm{m}$ ) so that a size-related wavelength dependence of backscattering and extinction is not very likely.

The lidar-ratio observations at three wavelengths in the right panel in Fig. 3 are the highlight of the study. The lidarratio profiles show similar vertical structures for all three wavelengths. The slight differences between the effective lidar ratios (not corrected for the MS effect) may point to the different impact of MS for the different wavelengths. The cirrus lidar ratios for 532 and $1064 \mathrm{~nm}$ are almost equal with values around $22.5-25 \mathrm{sr}$ at cirrus base to about $35-40 \mathrm{sr}$ at cirrus top. The $355 \mathrm{~nm}$ values are $3-5 \mathrm{sr}$ lower than the $532 \mathrm{~nm}$ lidar ratios. Taking the MS effect into account with an average MS factor of about 0.8 for the $4 \mathrm{~km}$ deep cirrus layer, we end up with MS-corrected cirrus mean lidar ratios around $31 \mathrm{sr}$ for $355 \mathrm{~nm}, 36 \mathrm{sr}$ for $532 \mathrm{~nm}$, and $38 \mathrm{sr}$ for $1064 \mathrm{~nm}$ for this single cirrus event. The variability around these mean values is of the order of $5 \mathrm{sr}$.

There are numerous reports on cirrus lidar ratios in the literature for comparison. However, clear statements on MS correction and laser pointing (zenith pointing or off-zenith pointing) are often missing so that comparisons are difficult. Seifert et al. (2007) reported BERTHA lidar observation of the cirrus clouds over the tropical Indian Ocean (Indian Ocean Experiment, 1999-2000). During the northeast monsoon season (polluted winter season) the MS-corrected mean cirrus lidar ratio was $33 \pm 9 \mathrm{sr}$ at $532 \mathrm{~nm}$ for offzenith pointing conditions and for cirrus layers between 9 and $18 \mathrm{~km}$ height. Chen et al. (2002) reported MS-corrected $532 \mathrm{~nm}$ cirrus lidar ratios of $35 \pm 15 \mathrm{sr}$ for the $12-15 \mathrm{~km}$ (comparably warm ice cloud) range over Taiwan for the years 1999 and 2000 obtained with an obviously zenithpointing lidar. Giannakaki et al. (2007) used an off-zenith pointing $355 \mathrm{~nm}$ backscatter lidar and found MS-corrected lidar ratios of $30 \pm 17 \mathrm{sr}$ in cirrus clouds over northern Greece in the Mediterranean for the 2002-2006 time period. Cirrus were observed between 9 and $13 \mathrm{~km}$ height with mid-cloud temperatures from -40 to $-65^{\circ} \mathrm{C}$. Josset et al. (2012) and Garnier et al. (2015) analyzed spaceborne CALIOP (Cloud Aerosol Lidar with Orthogonal Polarization) lidar observations, which were partly performed at zenith-pointing and off-zenith-pointing conditions. The authors concluded that the MS-corrected cirrus lidar ratio around the globe is typically $30-35 \mathrm{sr} \pm 5-8 \mathrm{sr}$ at $532 \mathrm{~nm}$. Garnier et al. (2015) found that the cirrus mean lidar ratios are on average around $35 \mathrm{sr}$ for comparably warm ice clouds 
with temperatures higher than about $-45^{\circ} \mathrm{C}$. The cirrus layer, discussed in Fig. 3, showed temperatures from $-25^{\circ} \mathrm{C}$ at $6.5 \mathrm{~km}$ height over $-36^{\circ} \mathrm{C}$ at $8 \mathrm{~km}$ height to about -50 $55^{\circ} \mathrm{C}$ at cirrus top. Thus our observation fits well into the published lidar-ratio climatologies. Furthermore, the simultaneous 532 and $1064 \mathrm{~nm}$ Raman lidar observations, which suggest wavelength-independent cirrus backscattering, extinction, and lidar ratio, corroborate that all the assumptions which have to be made in the CALIOP cirrus data analysis regarding wavelength dependence of cirrus optical properties in the 532-1064 nm spectral range are justified (Vaughan et al., 2010).

\subsection{Outlook: aerosol particle extinction profiling at $1064 \mathrm{~nm}$}

As mentioned above, the new method in its simplest configuration, without daylight suppression between the rotational Raman lines as suggested by Arshinov et al. (2005), is only applicable at nighttime hours because of the broad $9 \mathrm{~nm}$ interference filter width. In the following discussion, we illuminate the potential of two operational lidars regarding $1064 \mathrm{~nm}$ extinction profiling of aerosol layers in the lower troposphere (around $1.5 \mathrm{~km}$ height). These two lidars are BERTHA (with the key features: about $500 \mathrm{~mJ}$ pulse energy at $1064 \mathrm{~nm}, 30 \mathrm{~Hz}$ repetition rate, $53 \mathrm{~cm}$ telescope, photon counting with single-photon quantum efficiency of $0.08 \%$ ) and the NASA GSFC multiwavelength Raman lidar $(150 \mathrm{~mJ}$ pulse energy at $532 \mathrm{~nm}, 50 \mathrm{~Hz}$ repetition rate, $40 \mathrm{~cm}$ telescope, analog detection with avalanche photodiode, singlephoton quantum efficiency of close to $40 \%$ ) described in Veselovskii et al. (2013). We discuss scenarios with $1064 \mathrm{~nm}$ aerosol extinction values around $150 \mathrm{Mm}^{-1}$ (lofted mineral dust layer) and $50 \mathrm{Mm}^{-1}$ (more typical for smoke and pollution layers).

From our first cirrus observation with the new $1064 \mathrm{~nm}$ rotational Raman channel in the BERTHA system discussed above we can draw the following conclusions regarding aerosol extinction profiling at $1.5 \mathrm{~km}$ height. In Fig. 3, at 8$8.5 \mathrm{~km}$ height the measured $1064 \mathrm{~nm}$ extinction coefficient is $160 \mathrm{Mm}^{-1}$ (relative uncertainty $20 \%$ ). At $1.5 \mathrm{~km}$ height, the signal strength would be a factor of about 30 higher than at $8 \mathrm{~km}$ height due to the reduced distance from the lidar. By using the same temporal and vertical resolution as in Fig. 3, the relative uncertainty would thus decrease by roughly a factor of $5.5(\sqrt{30})$. To obtain aerosol extinction coefficients with an acceptable uncertainty of $20 \%$ (as in the cirrus case in Fig. 3), we can therefore reduce the smoothing length $\Delta R$ from 2500 to about $800 \mathrm{~m}$. The uncertainty decreases with $1 /(\Delta R)^{3 / 2}$ (Browell et al., 1979) when the solution follows from a difference quotient with the step with of $\Delta R$ as is the case in the extinction-coefficient retrieval. However, if the extinction coefficient is $50 \mathrm{Mm}^{-1}$ (typical for smoke and haze), we need a regression window length of $1600 \mathrm{~m}$ to keep the relative uncertainty close to $20 \%$. This means, even by using a powerful $1064 \mathrm{~nm}$ lidar such as BERTHA, the photon counting unit (with a PMT quantum efficiency of $0.08 \%$ ) is not appropriate for aerosol extinction profiling in the lower troposphere. Large signal averaging periods in combination with very large vertical regression window lengths are required to keep the uncertainties at a tolerable level of $20 \%$.

The NASA GSFC lidar makes use of analog detection at $1064 \mathrm{~nm}$, with a quantum efficiency a factor of almost 500 higher than the quantum efficiency (photon counting mode) of BERTHA. Veselovskii et al. (2015) present a $532 \mathrm{~nm}$ rotational Raman lidar measurement in terms of aerosol extinction, backscatter, and lidar-ratio profiles in the lower troposphere; $30 \mathrm{~min}$ of signal averaging was sufficient to obtain the particle extinction coefficients of about $150 \mathrm{Mm}^{-1}$ at $1.5 \mathrm{~km}$ height with a vertical resolution of $100 \mathrm{~m}$ and a relative uncertainty of $5-10 \%$. If we take the $\lambda^{-4}$ wavelength dependence of molecular scattering in the atmosphere into account, the rotational Raman signal strength in the $1064 \mathrm{~nm}$ wavelength range will be reduced by a factor of 16 . For simplicity, we ignore here changing overall transmitter and receiver transmission features when going from 532 to $1064 \mathrm{~nm}$. To keep the uncertainties below $10 \%$, we need to increase the signal averaging period by a factor of 2 (to $1 \mathrm{~h}$ signal averaging) and the vertical resolution must be decreased from 100 to $500 \mathrm{~m}$. If we further assume that the $1064 \mathrm{~nm}$ aerosol extinction coefficient is of the order of $50 \mathrm{Mm}^{-1}$, we still can have a reasonable resolution of about $750 \mathrm{~m}$ if we accept a higher uncertainty of about $20 \%$.

In the next step, we will implement a $1064 \mathrm{~nm}$ rotational Raman channel in a Polly system (Engelmann et al., 2016) and will make extensive aerosol observations with different detection methods. Both analog and photon-counting detection and combinations of both need to be checked and tested. Note that not only extinction profiling is of value. Lidarratio profiling at $1064 \mathrm{~nm}$ and thus backscatter coefficient profiling is of importance, too. There are practically no experimental data on the lidar ratio of the different dust types for $1064 \mathrm{~nm}$. Almost all assumed values in the respective $1064 \mathrm{~nm}$ backscatter-lidar retrievals rely on model computations. For an adequate backscatter profiling, the detection unit of the lidar receiver must be able to resolve 6 orders of magnitude of signal strength (from $1064 \mathrm{~nm}$ dust backscattering to almost pure $1064 \mathrm{~nm}$ Rayleigh backscattering) to allow proper calibration of the backscatter coefficient profiles. This is not possible by the use of analog detection.

\section{Conclusions}

We implemented a rotational Raman channel around $1058 \mathrm{~nm}$ in an operational multiwavelength polarization/Raman lidar in order to obtain measured particle extinction coefficient profiles at $1064 \mathrm{~nm}$. First measurements were performed in cirrus layers in October 2015. As expected, wavelength-independent cirrus backscattering 
was observed at all three wavelengths and also almost wavelength-independent extinction and lidar ratio at 532 and $1064 \mathrm{~nm}$.

We discussed to what extent a proper $1064 \mathrm{~nm}$ extinction profiling with appropriate resolution is possible in the case of the TROPOS lidar BERTHA and the NASA GSFC Raman lidar. We concluded that efficient photon detection is required to obtain aerosol extinction and lidar-ratio profiles with $10-20 \%$ relative uncertainty, $1 \mathrm{~h}$ temporal resolution, and vertical resolution of $750 \mathrm{~m}$.

We conclude that, in the next step, lidar observations of aerosol layers with different photon detection techniques (photon counting, analog detection, combination of both) are required with the goal of finding an optimized detection system for a $1064 \mathrm{~nm}$ rotational Raman lidar for aerosol extinction and lidar-ratio profiling. For proper extinction profiling at $1064 \mathrm{~nm}$, analog detection seems to be advantageous. More generally, an optimized receiver optics and signal detection concept for a $1058 \mathrm{~nm}$ Raman channel needs to be elaborated based on an extended study with an operational continuously running lidar such as Polly. Furthermore, Raman lidar observations at three wavelengths should focus on aerosol layers (boundary layer, lower free troposphere) at very different conditions regarding the contribution by urban haze, biomass burning smoke, marine particles, and desert dust. Emphasis should also be put on the comparison with accompanying Aerosol Robotic Network (AERONET) photometer observations from 340 to $1640 \mathrm{~nm}$ as recently demonstrated by Veselovskii et al. (2016) by using a stateof-the-art dual-wavelength Raman lidar.

Acknowledgements. We thank Johannes Bühl for providing Doppler lidar observations of vertical velocity and estimated ice crystal sizes. Modeling of the rotational Raman filter parameters was supported by the Russian Science Foundation (project no. 16-17-10241).

Edited by: V. Amiridis

Reviewed by: two anonymous referees

\section{References}

Alados-Arboledas, L., Müller, D., Guerrero-Rascado, J. L., NavasGuzmán, F., Pérez-Ramírez, D., and Olmo, F. J.: Optical and microphysical properties of fresh biomass burning aerosol retrieved by Raman lidar, and star-and sun-photometry, Geophys. Res. Lett., 38, L01807, doi:10.1029/2010GL045999, 2011.

Althausen, D., Müller, D., Ansmann, A., Wandinger, U., Hube, H., Clauder, E., and Zörner, S.: Scanning six-wavelength elevenchannel aerosol lidar, J. Atmos. Ocean. Tech.., 17, 1469-1482, doi:10.1175/1520-0426(2000)017<1469:SWCAL>2.0.CO;2, 2000.

Althausen, D., Oelsner, P., Rohmer, A., and Baars, H.: Comparison of High Spectral Resolution Lidar with Raman lidar, in :Reviewed and revised papers of the 26th International Laser Radar
Conference, edited by: Papayannis,A., Balis, D., and Amiridis, V., Vol. 1, 43-46, June 2012, Porto Heli, Greece, National Technical University of Athens, 2012.

Amiridis, V., Balis, D. S., Kazadzis, S., Bais, A., Giannakaki, E., Papayannis, A., and Zerefos, E.: Four-year aerosol observations with a Raman lidar at Thessaloniki, Greece, in the framework of European Aerosol Research Lidar Network (EARLINET), J. Geophys. Res., 110, D21203, doi:10.1029/2005JD006190, 2005.

Ansmann, A. and Müller, D., Lidar and atmospheric aerosol particles, in: LIDAR - Range-resolved optical remote sensing of the atmosphere, edited by: Weitkamp, C., Springer, New York, USA, 105-141, 2005.

Ansmann, A., Riebesell, M., and Weitkamp, C.: Measurements of atmospheric aerosol extinction profiles with a Raman lidar, Opt. Lett., 15, 746-748, doi:10.1364/OL.15.000746, 1990.

Ansmann, A., Wandinger, U., Riebesell, M., Weitkamp, C., and Michaelis, W.: Independent measurement of extinction and backscatter profiles in cirrus clouds by using a combined Raman elastic-backscatter lidar, Appl. Optics, 31, 7113-7131, 1992a.

Ansmann, A., Riebesell, M., Wandinger, U., Weitkamp, C., Voss, E., Lahmann, W., and Michaelis, W.: Combined Raman elasticbackscatter LIDAR for vertical profiling of moisture, aerosol extinction, backscatter, and LIDAR ratio, Appl. Phys. B, 55, 18-22, doi:10.1007/BF00348608, 1992b.

Ansmann, A., Wandinger, U., and Weitkamp, C.: One-year observations of Mount-Pinatubo aerosol with an advanced Raman lidar over Germany at 53.5 N, Geophys. Res. Lett., 20, 711-714, doi:10.1029/93GL00266, 1993.

Ansmann, A., Althausen, D., Wandinger, U., Franke, K., Müller, D., Wagner, F., Heintzenberg, J.: Vertical profiling of the Indian aerosol plume with six-wavelength lidar during INDOEX: A first case study, Geophys. Res. Lett., 27, 963-966, doi:10.1029/1999GL010902, 2000.

Ansmann, A., Wagner, F., Müller, D., Althausen, D., Herber, A., von Hoyningen-Huene, W., and Wandinger, U.: European pollution outbreaks during ACE 2: Optical particle properties inferred from multiwavelength lidar and star-Sun photometry, J. Geophys. Res., 107, 4259, doi:10.1029/2001JD001109, 2002.

Arshinov, Y., Bobrovnikov, S., Serikov, I., Ansmann, A., Wandinger, U., Althausen, D., Mattis, I., and Müller, D.: Daytime operation of a pure rotational Raman lidar by use of a Fabry-Perot interferometer, Appl. Optics, 44, 3593-3603, doi:10.1364/AO.44.003593, 2005.

Baars, H., Kanitz, T., Engelmann, R., Althausen, D., Heese, B., Komppula, M., Preißler, J., Tesche, M., Ansmann, A., Wandinger, U., Lim, J.-H., Ahn, J. Y., Stachlewska, I. S., Amiridis, V., Marinou, E., Seifert, P., Hofer, J., Skupin, A., Schneider, F., Bohlmann, S., Foth, A., Bley, S., Pfüller, A., Giannakaki, E., Lihavainen, H., Viisanen, Y., Hooda, R. K., Pereira, S. N., Bortoli, D., Wagner, F., Mattis, I., Janicka, L., Markowicz, K. M., Achtert, P., Artaxo, P., Pauliquevis, T., Souza, R. A. F., Sharma, V. P., van Zyl, P. G., Beukes, J. P., Sun, J., Rohwer, E. G., Deng, R., Mamouri, R.-E., and Zamorano, F.: An overview of the first decade of PollyNET: an emerging network of automated Raman-polarization lidars for continuous aerosol profiling, Atmos. Chem. Phys., 16, 5111-5137, doi:10.5194/acp-165111-2016, 2016. 
Browell, E., Wilkerson, T., and Mcilrath, T.: Water vapor differential absorption lidar development and evaluation, Appl. Optics 18, 3474-3483, doi:10.1364/AO.18.003474, 1979.

Burton, S. P., Ferrare, R. A., Hostetler, C. A., Hair, J. W., Rogers, R. R., Obland, M. D., Butler, C. F., Cook, A. L., Harper, D. B., and Froyd, K. D.: Aerosol classification using airborne High Spectral Resolution Lidar measurements - methodology and examples, Atmos. Meas. Tech., 5, 73-98, doi:10.5194/amt-5-73-2012, 2012.

Chen, W.-N., Chiang, C.-W., and Nee, J.-B.: Lidar ratio and depolarization ratio for cirrus clouds, Appl. Optics, 41, 6470-6476, doi:10.1364/AO.41.006470, 2002.

Eloranta, E. W.: High spectral resolution lidar, in: Lidar: Rangeresolved Optical Remote Sensing of the Atmosphere, edited by: Weitkamp, K., Springer, New York, USA, 143-163, 2005.

Engelmann, R., Kanitz, T., Baars, H., Heese, B., Althausen, D., Skupin, A., Wandinger, U., Komppula, M., Stachlewska, I. S., Amiridis, V., Marinou, E., Mattis, I., Linné, H., and Ansmann, A.: The automated multiwavelength Raman polarization and water-vapor lidar Polly ${ }^{\mathrm{X}}$ : the neXT generation, Atmos. Meas. Tech., 9, 1767-1784, doi:10.5194/amt-9-1767-2016, 2016.

Esselborn, M., Wirth, M., Fix, A., Tesche, M., and Ehret, G.: Airborne high spectral resolution lidar for measuring aerosol extinction and backscatter coefficients, Appl. Optics 47, 346-358, doi:10.1364/AO.47.000346, 2008.

Ferrare, R. A., Melfi, S. H., Whiteman, D. N., and Evans, K. D.: Raman lidar measurements of Pinatubo aerosols over southeastern Kansas during November-December 1991, Geophys. Res. Lett., 19, 1599-1602, doi:10.1029/92GL01473, 1992

Ferrare, R. A., Melfi, S. H., Whiteman, D. N., Evans, K. D., and Leifer, R.: Raman lidar measurements of aerosol extinction and backscattering: 1. Methods and comparisons, J. Geophys. Res., 103, 19663-19672, doi:10.1029/98JD01646, 1998.

Franke, K., Ansmann, A., Müller, D., Althausen, D., Venkataraman, C., Reddy, M. S., Wagner, F., and Scheele, R.: Optical properties of the Indo-Asian haze layer over the tropical Indian Ocean, J. Geophys. Res., 108, 4059, doi:10.1029/2002JD002473, 2003.

Garnier, A., Pelon, J., Vaughan, M. A., Winker, D. M., Trepte, C. R., and Dubuisson, P.: Lidar multiple scattering factors inferred from CALIPSO lidar and IIR retrievals of semi-transparent cirrus cloud optical depths over oceans, Atmos. Meas. Tech., 8, 27592774, doi:10.5194/amt-8-2759-2015, 2015.

Giannakaki, E., Balis, D. S., Amiridis, V., and Kazadzis, S.: Optical and geometrical characteristics of cirrus clouds over a Southern European lidar station, Atmos. Chem. Phys., 7, 5519-5530, doi:10.5194/acp-7-5519-2007, 2007.

Groß, S., Tesche, M., Freudenthaler, V., Toledano, C., Wiegner, M., Ansmann, A., Althausen, D., and Seefeldner, M.: Characterization of Saharan dust, marine aerosols and mixtures of biomassburning aerosols and dust by means of multi-wavelength depolarization and Raman lidar measurements during SAMUM 2, Tellus B, 63, 706-724, doi:10.1111/j.1600-0889.2011.00556.x, 2011.

Groß, S., Freudenthaler, V., Wiegner, M., Gasteiger, J., Geiß, A., and Schnell, F.: Dual-wavelength linear depolarization ratio of volcanic aerosols: Lidar measurements of the Eyjafjallajökull plume over Maisach, Germany, Atmos. Environ., 48, 85-96, 2012.

Grund, C. J. and Eloranta, E. W.: The 27-28 October 1986 FIRE IFO Cirrus Case Study: Cloud Optical Prop- erties Determined by High Spectral Resolution Lidar, Mon. Weather Rev. 118, 2344-2355, doi:10.1175/15200493(1990)118<2344:TOFICC>2.0.CO;2, 1990.

Haarig, M., Althausen, D., Ansmann, A., Klepel, A., Baars, H., Engelmann, R., Groß, S., and Freudenthaler, V.: Measurement of the linear depolarization ratio of aged dust at three wavelengths (355, 532 and $1064 \mathrm{~nm})$ simultaneously over Barbados, in: Proceedings of the 27th Interntaional Laser Radar Conference, New York City, USA, 5-10 July 2015, S8b.04, 2015.

Haarig, M., Althausen, D., Ansmann, A., Engelmann, R., Baars, H., Klepel, A., Groß, S., Freudenthaler, V., Burton, S. P., Marinou, E., and Gasteiger, J.: Triple-wavelength depolarizationratio profiling with lidar in Saharan dust over Barbados during SALTRACE 2013 and 2014, in prepartion for ACP SALTRACE Special Issue, 2016.

Hair, J., Caldwell, L., Krueger, D., and She, C., High-SpectralResolution Lidar with Iodine-Vapor Filters: Measurement of Atmospheric-State and Aerosol Profiles, Appl. Optics, 40, 52805294, doi:10.1364/AO.40.005280, 2001.

Hair, J. W., Hostetler, C. A., Cook, A. L., Harper, D. B., Ferrare, R. A., Mack, T. L., Welch, W., Izquierdo, L. R., and Hovis, F. E.: Airborne high-spectral-resolution lidar for profiling aerosol optical profiles, Appl. Optics, 47, 6734-6752, doi:10.1364/AO.47.006734, 2008.

Illingworth, A. J., Barker, H. W., Beljaars, A., Ceccaldi, M., Chepfer, H., Clerbaux, N., Cole, J., Delanoe, J., Domenech, C., Donovan, D. P., Fukuda, S., Hirakata, M., Hogan, R. J., Hünerbein, H., Kollias, P., Kubota, T., Nakajima, T., Nakajima, T. Y., Nishizawa, T., Ohno, Y., Okamoto, H., Oki, R., Sato, K., Satoh, M., Shephard, M., Velázquez-Blázquez, A., Wandinger, U., Wehr, T., and Zadelhoff, G.-J.: THE EARTHCARE SATELLITE: the next step forward in global measurements of clouds, aerosols, precipitation and radiation, B. Am. Meteorol. Soc., 96, 1311-1332, doi:10.1175/BAMS-D-1200227.1, 2015.

Josset, D., Pelon, J., Garnier, A., Hu, Y., Vaughan, M., Zhai, P.W., Kuehn, R., and Lucker, P.: Cirrus optical depth and lidar ratio retrieval from combined CALIPSO-CloudSat observations using ocean surface echo, J. Geophys. Res., 117, D05207, doi:10.1029/2011JD016959, 2012.

Kanitz, T., Engelmann, R., Heinold, B., Baars, H., Skupin, A., and Ansmann, A.: Tracking the Saharan Air Layer with shipborne lidar across the tropical Atlantic, Geophys. Res. Lett., 41, 1044 1050, doi:10.1002/2013GL058780, 2014.

Mattis, I., Ansmann, A., Müller, D., Wandinger, U., and Althausen, D.: Dual-wavelength Raman lidar observations of the extinctionto-backscatter ratio of Saharan dust, Geophys. Res. Lett., 29, 201-20-4 , doi:10.1029/2002GL014721, 2002.

Mattis, I., Ansmann, A., Müller, D., Wandinger, U., and Althausen, D.: Multiyear aerosol observations with dual-wavelength Raman lidar in the framework of EARLINET, J. Geophys. Res., 109, D13203, doi:10.1029/2004JD004600, 2004.

Mona, L., Papagiannopoulos, N., Basart, S., Baldasano, J., Binietoglou, I., Cornacchia, C., and Pappalardo, G.: EARLINET dust observations vs. BSC-DREAM8b modeled profiles: 12year-long systematic comparison at Potenza, Italy, Atmos. Chem. Phys., 14, 8781-8793, doi:10.5194/acp-14-8781-2014, 2014.

Müller, D., Wandinger, U., Althausen, D., Mattis, I., and Ansmann, A.: Retrieval of physical particle properties from lidar observa- 
tions of extinction and backscatter at multiple wavelengths, Appl. Optics, 37, 2260-2263, doi:10.1364/AO.37.002260, 1998.

Müller, D., Wandinger, U., and Ansmann, A.: Microphysical particle parameters from extinction and backscatter lidar data by inversion with regularization: theory, Appl. Optics, 38, 2346-2357, doi:10.1364/AO.38.002346, 1999.

Müller, D., Wagner, F., Althausen, D., Wandinger, U., and Ansmann, A.: Physical properties of the Indian aerosol plume derived from six-wavelength lidar observations on 25 March 1999 of the Indian Ocean Experiment, Geophys. Res. Lett., 27, 14031406, doi:10.1029/1999GL011217, 2000.

Müller, D., Mattis, I., Wandinger, U., Ansmann, A., Althausen, D., and Stohl, A.: Raman lidar observations of aged Siberian and Canadian forest fire smoke in the free troposphere over Germany in 2003: Microphysical particle characterization, J. Geophys. Res., 110, D17201, doi:10.1029/2004JD005756, 2005.

Müller, D., Ansmann, A., Mattis, I., Tesche, M., Wandinger, U., Althausen, D., and Pisani, G.: Aerosol-type-dependent lidar ratios observed with Raman lidar, J. Geophys. Res., 112, D16202, doi:10.1029/2006JD008292, 2007.

Müller, D., Lee, K.-H., Gasteiger, J., Tesche, M., Weinzierl, B., Kandler, K., Müller, T., Toledano, C., Otto, S., Althausen, D., and Ansmann, A.: Comparison of optical and microphysical properties of pure Saharan mineral dust observed with AERONET Sun photometer, Raman lidar, and in situ instruments during SAMUM 2006, J. Geophys. Res., 117, D07211, doi:10.1029/2011JD016825, 2012.

Müller, D, Veselovskii, I, Kolgotin, A, Tesche, M, Ansmann, A, and Dubovik, O.: Vertical profiles of pure dust and mixed smokedust plumes inferred from inversion of multiwavelength Raman/polarization lidar data and comparison to AERONET retrievals and in situ observations, Appl. Optics, 52, 3178-3202, doi:10.1364/AO.52.003178, 2013.

Murayama, T., Müller, D., Wada, K., Shimizu, A., Sekiguchi, M. and Tsukamoto, T.: Characterization of Asian dust and Siberian smoke with multiwavelength Raman lidar over Tokyo, Japan in spring 2003, Geophys. Res. Lett., 31, L23103, doi:10.1029/2004GL021105, 2004.

Nicolae, D., Nemuc, A., Müller, D., Talianu, C., Vasilescu, J., Belegante, L., and Kolgotin, A.: Characterization of fresh and aged biomass burning events using multiwavelength Raman lidar and mass spectrometry, J. Geophys. Res. Atmos., 118, 2956-2965, doi:10.1002/jgrd.50324, 2013.

Papayannis, A., Amiridis, V., Mona, L., Tsaknakis, G., Balis, D., Bösenberg, J., Chaikovski, A., De Tomasi, F., Grigorov, I., Mattis, I., Mitev, V., Müller, D., Nickovic, S., Pérez, C., Pietruczuk, A., Pisani, G., Ravetta, F., Rizi, V., Sicard, M., Trickl, T., Wiegner, M., Gerding, M., Mamouri, R. E., D’Amico, G., and Pappalardo, G.: Systematic lidar observations of Saharan dust over Europe in the frame of EARLINET (2000-2002), J. Geophys. Res., 113, D10204, doi:10.1029/2007JD009028, 2008.

Pappalardo, G., Amodeo, A., Pandolfi, M., Wandinger, U., Ansmann, A., Bösenberg, J., Matthias, V., Amiridis, V., De Tomasi, F., Frioud, M., Iarlori, M., Komguem, L., Papayannis, A., Rocadenbosch, F., and Wang, X.: Aerosol lidar intercomparison in the framework of the EARLINET project. 3. Raman lidar algorithm for aerosol extinction, backscatter, and lidar ratio, Appl. Optics, 43, 5370-5385, doi:10.1364/AO.43.005370, 2004.
Pappalardo, G., Amodeo, A., Apituley, A., Comeron, A., Freudenthaler, V., Linné, H., Ansmann, A., Bösenberg, J., D’Amico, G., Mattis, I., Mona, L., Wandinger, U., Amiridis, V., AladosArboledas, L., Nicolae, D., and Wiegner, M.: EARLINET: towards an advanced sustainable European aerosol lidar network, Atmos. Meas. Tech., 7, 2389-2409, doi:10.5194/amt-7-23892014, 2014.

Seifert, P., Ansmann, A., Müller, D., Wandinger, U., Althausen, D., Heymsfield, A. J., Massie, S. T., and Schmitt, C.: Cirrus optical properties observed with lidar, radiosonde, and satellite over the tropical Indian Ocean during the aerosol-polluted northeast and clean maritime southwest monsoon, J. Geophys. Res., 112, D17205, doi:10.1029/2006JD008352, 2007.

Shipley, S. T., Tracy, D. H., Eloranta, E. W., Trauger, J. T., Sroga, J. T., Roesler, F. L., and Weinman, J. A.: High Spectral Resolution Lidar to measure optical-scattering properties of atmospheric aerosols, 1. Theory and instrumentation, Appl. Optics, 22, 3716-3724, doi:10.1364/AO.22.003716, 1983

Tesche, M., Ansmann, A., Müller, D., Althausen, D., Engelmann, R., Freudenthaler, V., and Groß, S.: Vertically resolved separation of dust and smoke over Cape Verde using multiwavelength Raman and polarization lidars during Saharan Mineral Dust Experiment 2008, J. Geophys. Res., 114, D13202, doi:10.1029/2009JD011862, 2009a.

Tesche, M., Ansmann, A., Müller, D., Althausen, D., Mattis, I., Heese, B., Freudenthaler, V., Wiegner, M., Esselborn, M., Pisani, G., and Knippertz, P.: Vertical profiling of Saharan dust with Raman lidars and airborne HSRL in southern Morocco during SAMUM, Tellus B, 61, 144-164, doi:10.1111/j.16000889.2008.00390.x, 2009b.

Tesche, M., Groß, S., Ansmann, A., Müller, D., Althausen, D., Freudenthaler, V., and Esselborn, M.: Profiling of Saharan dust and biomass-burning smoke with multiwavelength polarization Raman lidar at Cape Verde, Tellus B, 63, 649-676, doi:10.1111/j.1600-0889.2011.00548.x, 2011.

Turner, D. D., Ferrare, R. A., and Brasseur, L. A.: Average aerosol extinction and water vapor profiles over the Southern Great Plains, Geophys. Res. Lett., 28, 4441-4444, doi:10.1029/2001GL013691, 2001

Vaughan, M. A., Liu, Z., McGill, M. J., Hu, Y., and Obland, M. D.: On the spectral dependence of backscatter from cirrus clouds: Assessing CALIOP's $1064 \mathrm{~nm}$ calibration assumptions using cloud physics lidar measurements, J. Geophys. Res., 115, D14206, doi:10.1029/2009JD013086, 2010.

Veselovskii, I., Kolgotin, A., Griaznov, V., Müller, D., Wandinger, U., and Whiteman, D.,: Inversion with regularization for the retrieval of tropospheric aerosol parameters from multiwavelength lidar sounding, Appl. Optics, 41, 3685-3699, doi:10.1364/AO.41.003685, 2002.

Veselovskii, I., Whiteman, D. N., Korenskiy, M., Kolgotin, A., Dubovik, O., Perez-Ramirez, D., and Suvorina, A.: Retrieval of spatio-temporal distributions of particle parameters from multiwavelength lidar measurements using the linear estimation technique and comparison with AERONET, Atmos. Meas. Tech., 6, 2671-2682, doi:10.5194/amt-6-2671-2013, 2013.

Veselovskii, I., Whiteman, D. N., Korenskiy, M., Suvorina, A., and Pérez-Ramírez, D.: Use of rotational Raman measurements in multiwavelength aerosol lidar for evaluation of parti- 
cle backscattering and extinction, Atmos. Meas. Tech., 8, 41114122, doi:10.5194/amt-8-4111-2015, 2015.

Veselovskii, I., Goloub, P., Podvin, T., Bovchaliuk, V., Derimian, Y., Augustin, P., Fourmentin, M., Tanre, D., Korenskiy, M., Whiteman, D. N., Diallo, A., Ndiaye, T., Kolgotin, A., and Dubovik, O.: Retrieval of optical and physical properties of African dust from multiwavelength Raman lidar measurements during the SHADOW campaign in Senegal, Atmos. Chem. Phys., 16, 70137028, doi:10.5194/acp-16-7013-2016, 2016.

Wandinger, U., Müller, D., Böckmann, C., Althausen, D., Matthias, V., Bösenberg, J, Weiß, V., Fiebig, M., Wendisch, M., Stohl, A., and Ansmann. A.: Optical and microphysical characterization of biomass-burning and industrial-pollution aerosols from multiwavelength lidar and aircraft measurements, J. Geophys. Res., 107, 8125, doi:10.1029/2000JD000202,2002.
Whiteman, D. N.: Examination of the traditional Raman lidar technique. I. Evaluating the temperature-dependent lidar equations, Appl. Optics, 42, 2571-2592, doi:10.1364/AO.42.002571, 2003a.

Whiteman, D. N.: Examination of the traditional Raman lidar technique. II. Evaluating the ratios for water vapor and aerosols, Appl. Optics, 42, 2593-2608, doi:10.1364/AO.42.002593, 2003b. 